Кандидат філологічних наук, доцент, дочент кафедри англійської філології ДВНЗ “Ужгородський Національний Університет" https://orcid.org/0000-0002-3377-9706 Ужсгород, Україна, +38 (050)2892017 iryna.andrusiak@uzhnu.edu.ua

\title{
The lexical approach to EFL teaching: methodological foundations and pedagogical implications
}

Анотачія. Стаття присвячена дослідженню теоретичного підгрунтя лексичного підходу до навчання англійської мови як іноземної. Використання лексичного підходу є своєрідним викликом традиційній дихотомії граматикалексика, відповідно до якої мова розглядається як система граматичних структур та набір ізольованих лексичних одиниць. Лексичний підхід відноситься до низки альтернативних підходів $i$ методів навчання англійської мови, яким, як правило, майже не приділясться увага в теорії та практиці навчання. Цим зумовлена актуальність проведеного дослідження. Ефективне застосування будь-якого нового підходу, методу, стратегії залежсить від поєднання двох факторів: глибокої теоретичної обізнаності вчителя з його основами та вміння застосовувати на практиці. Метою иієї статті є з'ясування суті лексичного підходу в процесі навчання англійської мови Основна увага приділяється гіпотезі фрази як теоретичному підгрунтю лексичного підходу та типології лексичних одиниць, розробленої в межах досліджуваного підходу.

Ключові слова: англійська мова як іноземна, лексичний підхід, гіпотеза фрази, правильність мовлення, плавність мовлення, лексика, лексична одиниця, колокаиія.

Abstract. The present paper explores the theoretical basis of the lexical approach to EFL teaching. The lexical approach to EFL teaching was introduced as an alternative to grammar-based foreign language teaching to challenge the traditionally accepted dichotomy grammar-lexis according to which language was viewed as a system of grammatical structures and a set of isolated vocabulary items. It gave priority to lexis to acknowledge that lexical phrases or chunks are the raw data by which learners perceive patterns of language traditionally thought of as grammar. Alongside the total physical response, the silent way, suggestopedia, community language learning, multiple intelligences, etc., the lexical approach is referred to a set of alternative approaches and methods in 
language teaching which are hardly ever addressed by national EFL curricula. Therefore, the research focusing on the methodological foundations underlying the lexical approach and its pedagogical implications for EFL teaching proves to be topical. Effective application of any new teaching technique in the EFL classroom implies the combination of teacher's awareness of its theoretical basis and practical skills to put it to practice. In this respect, the present paper aims to describe what the lexical approach means with a special focus on the lexical phrase hypothesis as its theoretical basis and the typology of lexical units.

Keywords: English as a foreign language, lexical approach, lexical phrase hypothesis, accuracy, fluency, vocabulary, lexical unit, collocation.

Introduction The lexical approach to EFL teaching was first introduced in the 1990s as an alternative to grammar-based foreign language teaching. Since it lays a heavy emphasis on lexis (not grammar), it was considered to be a revolutionary approach. More specifically, at that time the lexical approach challenged the traditionally accepted dichotomy grammar-lexis according to which language was viewed as a system of grammatical structures and a set of isolated vocabulary items. Hence, vocabulary was considered to be inferior to grammar providing building blocks for grammatical structures. On the contrary, the lexical approach gave priority to lexis to acknowledge that in language lexis is central in creating meaning with grammar playing a secondary role in conveying the meaning [27]. Moreover, according to the lexical approach, lexical phrases or chunks are the raw data by which learners perceive patterns of language traditionally thought of as grammar [14, p. 95].

The lexical approach was intended as the best description of language acquisition processes that equipped learners with the tools to put 'proper words in proper places' [1, p. 2]. The lexical approach acknowledges the importance of 'prefabricated' vocabulary (Rhalmi's term) which constitutes a considerable portion of a native speaker's output, both written and spoken [27]. Largely, speaker's fluent production results from, first, having at their disposal these prefabricated elements and, second, having a rapid access to them rather than having a set of grammar rules and a separate stock of isolated words. Hence, the lexical approach advocates the idea that the ability to comprehend and produce lexical phrases as unanalyzed wholes, or 'chunks' is an important part of language acquisition [21].

Hence, it follows that while teaching a foreign language the teacher should focus mostly on learners' developing a vast stock of lexical items the fluency of their written and spoken output depends on.

In foreign language teaching, a search for the most effective way is one of the tasks applied linguists has been trying to fulfil over a century. There has been a lot of debate and discussion about the centrality of grammar and vocabulary in the language curriculum, the importance of accuracy and fluency in the learners' language development, effective methods, approaches and learning strategies of 
EFL teaching. Although much has been done to solve the most debatable problems, the teaching profession is continually exploring new ways of addressing teaching and learning options to establish more effective teaching and learning practices. Alongside the total physical response, the silent way, suggestopedia, community language learning, multiple intelligences, etc., the lexical approach is referred to a set of alternative approaches and methods in language teaching which are hardly ever addressed by national EFL curricula. Therefore, the research focusing on the methodological foundations underlying the lexical approach and its pedagogical implications for EFL teaching proves to be highly topical.

It is commonly accepted that vocabulary as well as grammar are central to language acquisition. However, in contrast to grammar, vocabulary teaching in EFL school classrooms does not prove to be effective. The degree to which vocabulary should be taught, corrected and worked on and methods which should be employed are widely disputed in teaching industry. Recently, vocabulary teaching focus has been shifted to teaching more or less fixed strings of words in contrast to word lists. The latter has been the most popular strategy that both teachers and learners employ throughout a great many years. It results in a great number of deviant usages in learners' meaningful output (i.e. in speaking and writing), such as 'sit on the bus', 'suggested to open the window', 'finish university', etc. [11]. The obvious danger of the word-list strategy is that it provides students with the main components of the word knowledge (i.e. pronunciation, word class, meaning(s), derivatives) in isolation without exposing them to the contexts of real language use where words tend to come in collocations [22]. Hence, at present the number of researchers displaying interest in the use of alternative strategies in the teaching and learning foreign language vocabulary is growing. The main areas of their research interest are the essence of the lexical approach $[10 ; 13 ; 14 ; 20 ; 23]$, the possible dangers of the lexical approach $[16 ; 17$; $25]$, the typology of lexical units $[13 ; 14 ; 16 ; 17 ; 22 ; 23]$; implication for teaching $[27 ; 28 ; 30]$; psycholinguistic and corpora issues $[2 ; 3 ; 4 ; 5 ; 6 ; 8 ; 18 ; 24]$.

Effective application of any new teaching technique in the EFL classroom, the lexical approach inclusive, implies the combination of teacher's awareness of its theoretical basis and practical skills to put it to practice. In this respect, the present paper aims to describe what the lexical approach means with a special focus on the lexical phrase hypothesis as its theoretical basis and the typology of lexical units.

Research Methodology. Since the present study focuses on theoretical basis of the lexical approach to EFL teaching, it makes use of the research methods accepted and recognised in EFL education. First, the choice of methods and approaches for the present paper results from the status of English as a foreign language in the context of Ukrainian education. English as a foreign language is defined as the English language which is taught and learnt in countries where the official language is not English. Teaching English as a foreign language differs from teaching English as a second language in terms of the available language 
environment, which influences the teacher's choice of methods and techniques to use in EFL classroom. Our general research paradigm is also based on the communicative approach to EFL teaching which has dominated the EFL field for almost half a century. In accordance with this approach, teaching English vocabulary is regarded within the framework of the development of learners' communicative competence. More specifically, teaching vocabulary according to the lexical approach involves teaching all aspects of language construction and skills. The key points of the lexical phrase hypothesis that underlies the lexical approach to EFL teaching as well as basic types of lexical units elaborated within the framework of the approach in question are explored by analysing and reviewing the professional pedagogical, psychological and methodological literature.

Results and Discussion. The lexical approach traces its roots back to the 1990s when two Michael Lewis's books were published: 'The Lexical Approach: the State of ELT and a Way Forward' (1993) and 'Implementing the Lexical Approach - Putting Theory into Practice' (1997) [13; 14]. The books laid the key principles of the lexical approach:

- $\quad$ Language consists of grammaticalized lexis, not lexicalized grammar.

- The grammar/vocabulary dichotomy is invalid; much language consists of multi-word "chunks".

- A central element of language teaching is raising students' awareness of, and developing their ability to "chunk" language successfully.

- $\quad$ Although structural patterns are acknowledged as useful, lexical and metaphorical patterning are accorded appropriate status.

- Collocation is integrated as an organising principle within syllabuses.

- Grammar as structure is subordinate to lexis.

- $\quad$ Successful language is a wider concept than accurate language [13; 14].

The main premise underlying the lexical approach is the Lexical Phrase Hypothesis (hereinafter LPH). In M. West's words, the hypothesis reads as follows: 'An important part of language acquisition is the ability to comprehend and produce lexical phrases as unanalyzed wholes, or 'chunks', and that these chunks become the raw data by which learners perceive patterns of language traditionally thought of as grammar' [14, p. 95]. According to the hypothesis, many lexical phrases are not only used as combinations of words but are also stored in our mental lexicon and processed as if they were single words.

The rationale behind the LPH is the belief that learners of a foreign language benefit from treating strings of words as chunks in a number of ways. First, this increases fluency in all types of communicative activities (speaking, reading, listening and writing) and, second, enhances comprehension while reading and listening in general and while listening to fast speech in particular [16].

Fluency is understood as 'the ability native speakers have to produce long strings of speech which exceed their capacity for encoding and decoding speech' 
[27, p. 214]. One of the aims of foreign language teaching is develop learners' fluency which is believed to result in accuracy [30, p. 4]. A number of researchers suggest that fluency results from memorizing pre-fabricated language, however, they use different terms to refer to this issue: 'lexicalised sentence stems' and 'memorised strings' [27, p. 214]; 'chunks' and 'lexical phrases' [23, p. 21]. In other words, fluency comes from the ability to efficiently retrieve pre-fabricated units from learners' mental lexicon. This enables learners to direct their attention to the larger structure of the discourse rather than keep it narrowly focused on individual words as they are produced [11, p. 80].

There is a considerable body of psychological research to substantiate the idea that human mind stores and processes chunks as individual unanalyzed wholes. More specifically, the human mind can store a considerable amount of knowledge in long-term memory, yet its short-term memory has the capacity to process small amount of it in real time [3]. The evidence comes from the following: recurrent strings of words are highly predictable because they are stored as chunks; hence, they require less activation of our mind and less time in order to process them both when receiving input (when reading and listening) in a foreign language and when producing output (when writing and speaking). On the contrary, constructing speech from individual words and breaking speech into smaller parts each time we need to produce or receive language takes much more time.

Another advantage of the LPH is that lexical phrases provide learners with contextual models of real language use.

Much of the foundation for the LPH is set up on the basis of the data provided by applied and corpus linguistics. Corpus linguists use the term 'lexical bundle' to refer to lexical phrases or very common continuous strings of words, which may span phrasal boundaries (e.g. I don't know whether, don't worry about it, and in the middle of the) $[29$, p. 258]. Lexical bundles are members of a larger family of diverse lexical units known as holistic units. A significant body of research in the first language acquisition suggests that lexical bundles are stored holistically as unanalyzable wholes that is without internal structure $[4 ; 5 ; 29 ; 31]$. According to research findings in the first language acquisition, children first learn chunks to break them into smaller units at a later stage. In its turn, this suggests that some complex linguistic units we acquire must have 'a holistic entry node' $[29$, p. 271]. However, human brain processes input by pattern recognition and categorization. Humans are claimed to be the best pattern-recognition machines [2]. The process of pattern recognition involves analyzing and decomposing things.

In Lindstromberg's opinion, the lexical phrase hypothesis exists in two versions: weak and strong [16]. It should be noted that the words 'weak' and 'strong' do not denote the strength of scholarly argumentation. Instead, they relate to the degree to which language is assumed to consist of lexical phrases. According to the strong view, language-in-use comprises a very large proportion of lexical 
phrases. The weak version admits the fact that language is made up of lexical phrases but claims that their proportion is significant but not overwhelming.

M. Lewis, the founder of the approach, advocates the strong version of the lexical phrase hypothesis. Moreover, in terms of the whole approach the scholar believes that its methods have to replace all methodology in EFL classroom and suggests the Observe-Hypothesise-Experiment cyclical paradigm be employed instead of the Present-Practise-Produce paradigm [14, p. vii].

The Observe-Hypothesise-Experiment cycle, as its name implies, involves three-step procedure according to which learning a foreign language takes place. First, when learners receive language input either in a written form through reading or in an oral form through listening, they observe language in use. Observation involves critical examination of language or consciousness raising which is a prerequisite to noticing its features. After noticing, identifying and analysing these features learners hypothesise about the way language works. Finally, learners test their hypotheses by experimenting with producing language in different contexts [19].

Those who support the weak version of the lexical phrase hypothesis regard the lexical approach tools as complementary to available classroom techniques [30, p. 42]. Speaking about M. Lewis's list of 20 key principles of the lexical approach, $\mathrm{S}$. Granger notes that it contains some of the radical statements that are rejected by a number of the proponents of the approach [9, p. 3]. One basic disagreement between strong and weak versions deals with grammar/lexis issue in terms of language competence. S. Lindstromberg presents a commonly held view of language competence with regard to both output and input in the following way:

- In speaking and writing:

intended meanings $=>$ word $s+$ grammar $/$ morphology $=>$ meaningful output

- In listening and reading: input $=>$ grammar + words $=>$ understood meanings [16].

Before the advent of the lexical approach, the popular belief was that a moderately substantial knowledge of grammar and a few thousand words are needed for effective communication. The belief was based on the view on our language ability according to which people have an outstanding ability to combine single words into bigger strings of words in no time to produce meaningful output and to analyse the input by parsing and understanding strings of words. Applying computer metaphor makes the description of our language ability even clearer: human memories are relatively small in a sense that they retain only a few thousand words and grammar rules to apply to them; but human on-line processors are very powerful since they perform combining and parsing operations with single words at lightning speed. Accordingly, in order to empower learners' onlineprocessors a wealth of time was spent on grammar.

On the contrary, the lexical approach, and the LPH in particular, holds that it is human ability to learn vocabulary that is exceptional but the ability to combine 
and parse this vocabulary when communicating is not. In other words, human memories are prodigious while on-line processors are very weak.

Accordingly, M. West advocates a shift from sentence grammar to word grammar that means discarding teaching/learning grammar in favour of teaching/ learning lexical phrases or chunks which are believed to subsume grammatical constructions. The proponents of the weak version regard both sentence grammar and word grammar as two essential components of grammatical competence which complement each other [9, p. 4]. According to the weak view, there is still a place for sentence grammar in language teaching and learning because it performs the organizing function.

Since the lexical approach was introduced, not only has an array of terms to apply to strings of words been established, but an abundance of typologies of these units have been developed. Most of the typologies are based on the structural criteria. Nattinger and DeCarrico established the form and function-based taxonomies of lexical units according to their structural and functional characteristics so that they can be applied in EFL teaching. Let us consider the structural typologies first.

According to the structural criteria (i.e. form), Nattinger and DeCarrico establish 4 categories of lexical units [23, p. 37-44]:

1. Polywords - fixed short phrases which perform the same functions as individual lexical items: e.g. for the most part, at any rate, all in all, by and large, etc.

2. Institutionalized expressions - lexical phrases of sentence length which function as separate utterances: proverbs, aphorisms, social interaction formulas (e.g. How do you do?; How are you?; have a nice day; once upon a time; long time no see, etc.)

3. Phrasal constraints - variable short- to medium-length lexical phrases which perform a variety of functions (summarizing, greeting, parting, exemplifying, etc.): e.g. a__ ago (a day ago, a very long time ago, etc.); in (in sort, in summary, etc.); for (for example, for instance, etc.); and

4. Sentence builders - lexical phrases which function as sentence framework: my point is that X; let me start by/with $X$; that reminds me of X, etc.

$S$. Lindstromberg's structural typology of lexical phrases is somewhat different:

1) polyword - at any rate, by and large, as well;

2) frame or slot - the [adj.]-er ... the [adj]-er; as [adj] ....as [adj]; so [adj] ...that; Little did ... realize that ...;

3) sentence head - Could you....., God only knows wh-...

4) sentence tail - ..., if you would.; ... and so on.

5) cliché - There's more than one way to skin a cat [16].

Another classification of lexical phrases within the framework of EFL teaching belongs to M. Lewis. The scholar introduced the term 'lexical item' to 
denote both single words and multi-word sequences [14]. According to M. Lewis, lexical items fall into the following categories:

1) words (e.g., book, pen) - the most common type of lexical items;

2) polywords (e.g., by the way, upside down)

3) collocations, or word partnerships (e.g., community service, absolutely convinced)

4) institutionalized utterances (e.g., I'll get it; We'll see; That'll do; If I were you ...; Would you like a cup of coffee?)

5) sentence frames and heads (e.g., That is not as ... as you think; The fact/suggestion/problem/danger was ...) and even text frames (e.g., In this paper we explore ...; Firstly ...; Secondly ...; Finally ... [) [14, p. 92-95]

Three structural typologies described above are compared in Table 1.

Table 1.

\section{The Comparison of the Structural Typologies of Lexical Units within the Framework of Lexical Approach}

\begin{tabular}{|l|l|l|}
\hline \multicolumn{1}{|c|}{$\begin{array}{c}\text { Nattinger and } \\
\text { DeCarrico }\end{array}$} & \multicolumn{1}{|c|}{ Lindstromberg } & \multicolumn{1}{c|}{ Lewis } \\
\hline & Polywords & Words \\
\hline Polywords & Polywords \\
\hline $\begin{array}{l}\text { Institutionalised } \\
\text { expressions }\end{array}$ & $\begin{array}{l}\text { Institutionalised } \\
\text { utterances }\end{array}$ \\
\hline Phrasal constraints & Frames or slots & $\begin{array}{l}\text { Sentence frames and } \\
\text { heads }\end{array}$ \\
\hline Sentence builders & $\begin{array}{l}\text { Sentence heads } \\
\text { Sentence tails }\end{array}$ & $\begin{array}{l}\text { Collocations / word } \\
\text { partnerships }\end{array}$ \\
\hline & Cliché & \multicolumn{2}{|c|}{} \\
\hline & & \\
\hline
\end{tabular}

The table shows that all structural typologies contain such a category as polywords. Nattinger and DeCarrico's sentence builders are broken into sentence heads and sentence tails in S. Lindstromberg's typology and into sentence frames and heads in M. Lewis's one. Yet, they all render the same idea. Nattinger and DeCarrico's phrasal constraints are frames and slots in S. Lindstromberg's typology. Two typologies (those of Nattinger and DeCarrico and Lewis) contain institutionalized expressions or utterances.

The categories which are completely different in both classifications are words (M. Lewis), clichés (S. Lindstromberg) and collocations or word partnerships (M. Lewis).

Hence, the categories in three typologies denote more or less similar lexical units. The differences result from different terminology used by the scholars. 
Lexical phrases like all recurrent multi-word sequences perform various discourse functions in the context of intercultural communication [15, p. 107]. Accordingly, they fall into 3 categories:

1. Social interactions - lexical phrases which reflect social relationships with regard to managing conversation (starting, maintaining and closing): e.g. clarifying (e.g. what did you mean by X?); expressing politeness (e.g. thanks very much); requesting (e.g. may $I X$ ?); responding (e.g. I see), etc.

2. Necessary topics - lexical phrases operating in specific domains of daily conversation and associated with their topics: e.g. shopping (e.g. how much is X/; too expensive; cost $X$ dollars); time (e.g. $a$ ago), etc.

3. Discourse devices - lexical phrases which perform coherent and cohesive functions connecting the meaning and structure of the discourse: e.g. fluency devices (e.g. you know); logical connectors (e.g. as a result), exemplifiers ( e.g. it's like) [23, p. 60-66].

Functional highlights of the lexical phrase are reflected in the alternative terms such as pre-fabricated language. Prefabricated sequences of words are also referred to as a formulaic sequence: 'A formulaic sequence is a sequence, continuous or discontinuous, of words or other elements, which is, or appears to be, prefabricated: that is, stored and retrieved whole from memory at the time of use, rather than being subject to generation or analysis by the language grammar' [31, p. 9].

Although these taxonomies were established with the aim to make them applicable to EFL teaching, Golebiewska argues, some issues need clarification [7, p. 19]. More specifically, some of the structural criteria like the length or the degree of invariability are vaguely defined: the terms like 'short', 'medium' and 'long' as well as 'relatively fixed' or 'low variability' are hardly ever sufficient for teachers to distinguish between different types of lexical units. Admitting that Nattinger and DeCarrico's typologies have some teaching potential as a descriptive tool, Wray claims that they are overloaded with subcategories which might be quite confusing in the teaching/learning context [31]. Hence, Nattinger and DeCarrico's categories of lexical items, Keller and Warner argue, can serve as a kind of introduction to conversation formulae rather than a useful EFL teaching framework [12, p. 64].

The categories in M. Lewis's typology overlap in a sense that some of the categories can be treated in a different way. For example, a polyword 'by the way' can be categorized as an institutionalized utterance when used in a conversation to introduce a new topic. None of the authors provide the definitions of the lexical items which can be used to establish clear-cut boundaries between the categories.

Conclusions. The main premise of the lexical approach is the Lexical Phrase Hypothesis. Accordingly, an important part of language acquisition is the ability to comprehend and produce lexical phrases as unanalyzed wholes, or 'chunks'. These phrases are regarded as building blocks both in speech reception and production. According to the hypothesis, many lexical phrases are not only used as 
combinations of words but are also stored in our mental lexicon and processed as if they were single words. Hence, introducing chunks into the EFL classroom has a number of benefits for students: it contributes to fluency in all types of communicative activities, enhances comprehension and provides learners with contextual models of real language use. In the professional literature two types of typologies of lexical units are established: structural and functional. The categories in both structural and functional typologies often overlap. None of the authors provide the definitions of the lexical items which can be used to establish clear-cut boundaries between the categories. Therefore, these typologies and terms are worth only scholarly description.

\section{REFERENCES}

1. Bareggi Christina. "Proper Words in Proper Places: Some 'Modest Proposals' for Introducing the Lexical Approach into Your English Class." Lang Matters. $\quad$ Issue $13 \quad$ (September 2006): 2-4, http://ppbm.langedizioni.com/varie/riviste/pdf/langmatters13.pdf

2. Basulto Dominic. "Humans are the World's Best Pattern-Recognition Machines, But for How Long?” Bigthink, 2016, http://bigthink.com/endlessinnovation/humans-are-the-worlds-best-pattern-recognition-machines-but-forhow-long.

3. Bolinger Dwight. "Meaning and Memory." Forum Linguisticum, No 1(1976): $1-14$.

4. Ellis C., Nick. "Emergentism, connectionism and language learning." Language Learning, 48 (1998): 631-664.

5. Ellis C., Nick. "Sequencing in SLA. Phonological Memory, chunking, and points of order." Studies in Second Language Acquisition, 18 (1996): 91 -126.

6. Eyckmans June. "Taking SLA Research to Interpreter-Training: does Knowledge of Phrases Foster Fluency?" Multilingualism and Applied Comparative Linguistics: Pedagogical Perspectives. Eds. Frank Boers, Jeroen Darquennes \& Rita Temmerman. Newcastle: Cambridge Scholars Publishing. Grant, Lynn, 2007. 89-104.

7. Golebiewska P. The comparison of the effectiveness of the Observe Hypothesise Experiment and the Presentation Practice Production models on teaching procedural language of circumlocution and stalling devices to Upper intermediate EFL students. A thesis submitted in partial fulfilment for the requirements of the degree of MA by Research at the University of CentralLancashire,2013, http://clok.uclan.ac.uk/9655/1/Golebiewska\%20Patrycja\%20Final\%20eThesis\%20\%28Master\%20Copy\%29.pdf.

8. Goulden R., Nation P., and Read J. "How Large Can a Receptive Vocabulary be?"//AppliedLinguistics,11(1990):341-363, 
http://www.victoria.ac.nz/lals/about/staff/publications/paul-nation/1990Goulden-Voc-size.pdf.

9. Granger S. From Phraseology to Pedagogy: Challenges and Prospects// Draft to The Phraseological View of Language: A Tribute to John Sinclair. Eds. Thomas Herbst, Susen Faulhaber, Peter Uhrig. Walter de Gruyter, 2012.

10. Herbst Th. The Phraseological View of Language: A Tribute to John Sinclair. Eds. Thomas Herbst, Susen Faulhaber, Peter Uhrig. Walter de Gruyter, 2012.

11. Junying Zh. and Xuefei. "Chunking - an Effective Approach to Vocabulary Teaching and Learning in College Classrooms." CELEA Journal, 30 (3): 7984, http://www.celea.org.cn/teic/73/73-79.pdf.

12. Keller Eric, and Warner T., Sylvia. Conversational Gambits: Real English Conversational Practices. Hove, England: Language Teaching Publications, 1988.

13. Lewis M. Implementing the Lexical Approach - Putting Theory into Practice. Heinle cengage, 2008.

14. Lewis M. The Lexical Approach: the State of ELT and a Way Forward. Heinle cengage, 2002.

15. Lin Yen-Liang. Discourse Functions of Recurrent Multi-word Sequences in Online and Spoken Intercultural Communication// Yearbook of Corpus Linguistics and Pragmatics 2013: New Domains and Methodologies. Ed. Jesus Romero-Trillo. Springer Science \& Business Media, 2013. 105-156.

16. Lindstromberg S. "My Good-Bye to the Lexical Approach." Humanising Language Teaching, 2 (2005), http://www.hltmag.co.uk/mar03/mart1.htm

17. Lindstromberg S., and Boers F. Teaching Chunks of Language: the Issue of Memory/l Humanising Language Teaching, 6 (2008), http://www.hltmag.co.uk/dec08/idea.htm.

18. McCarthy M., J. Touchstone: From Corpus to Course Book. Cambridge: Cambridge University Press, 2004.

19. MillinS.Observe-Hypothesize-Experiment.2011, https://sandymillin.wordpress.com/2011/05/15/observe-hypothesizeexperiment/

20. MillerJ.TeachingVocabularyChunkbyChunk, http://www.efltasks.org/file/lexical.

21. Moudraia O. "Lexical Approach to Second Language Teaching." ERIC Digest. 2001-06-00, https://www.ericdigests.org/2002-2/lexical.htm.

22. Nation I., S., Paul. Learning Vocabulary in Lexical Sets : Dangers and Guidelines// TESOL Journal, 9 (2000). - No 9 (2): 6-10.

23. Nattinger J., and DeCarrico, J. Lexical Phrases and Language Teaching. 上海外语教育出版社, 1992. 
24. Neuschatz S., Jeffrey, et al. "Comparison of the Efficacy of Two NameLearning Techniques: Expanding Rehearsal and Name-Face Imagery." The American Journal of Psychology, 118 (1) (2005): 79-102.

25. Nikmehr A. "Gambits in a New Light." International Journal of Applied Linguistics and English Literature, 2 (4) (2013): 228-239.

26. Pawley A., and Syder, H. "Two puzzles for linguistic theory: Native-like selection and native-like fluency." Language and Communication. Eds. J. Richards \& R. Schmidt. London: Longman, 1983. 191-226.

27. Rhalmi M. "The Lexical Approach.” My English Pages, September 29, 2009, http://www.myenglishpages.com/blog/lexical-approach/

28. Taylor G. "Teaching Gambits: the Effect of Instruction and Task Variation on the Use of Conversation Strategies by Intermediate Spanish Students." Foreign Language Annals, 35 (2) (2002): 171-189.

29. Tremblay A., Derwing, B., and Libben, G. "Are Lexical Bundles Stored and Processed as Single Units?" Working Papers of the Linguistics Circle of the UniversityofVictoria, 19(2009):258-279, https://www.academia.edu/17831384/Are_lexical_bundles_stored_and_proce ssed_as_single_units

30. Willis J., D., The Lexical Syllabus. London: Collins COBUILD, 1990.

31. Wray A. Formulaic Sequences and the Lexicon. Cambridge: Cambridge University Press, 2005. 